\title{
Less Than Once a Year
}

National Cancer Institute

\section{Source}

National Cancer Institute. Less Than Once a Year. NCI Thesaurus. Code C159850.

Happening less than one time during a year. 